\title{
A força da mudança
}

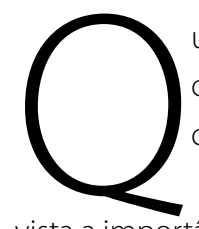

uando os membros do atual Plenário do Conselho Federal de Enfermagem ainda discutiam as propostas de campanha, uma foi unânime entre todos: a criação de um veículo de comunicação que expressasse a produção científica da Enfermagem Brasileira.

Hoje, com o primeiro número da Revista Enfermagem em Foco, mais um compromisso assumido é realizado, haja vista a importância do aprimoramento intelectual e a necessidade de melhor saber. E este veículo é um elo fundamental para que a enfermagem brasileira possa expressar sua produção intelectual; seu trabalho científico.

A missão primordial do veículo de comunicação é contribuir para o fortalecimento e desenvolvimento da profissão de enfermagem, divulgando conhecimentos relativos aos objetivos finalísticos do Sistema COFEN-CORENS, de normatizar e fiscalizar o exercício profissional, publicando artigos atinentes aos temas: Ética e Bioética em Saúde e Enfermagem; Fundamentos Teóricos e Jurídicos - Legais da Profissão; Organização Profissional da Enfermagem; Processo de Trabalho da Enfermagem; Filosofia da Enfermagem; Políticas Públicas em Saúde e Enfermagem, entre outros.

A revista é uma importante ferramenta, sobretudo, porque propicia o consumo crítico de toda produção científica relativa aos objetivos do Sistema. Além de disponibilizar aos profissionais de enfermagem e à comunidade científica, nacional e internacional, conhecimentos atualizados que fomentará o debate e o intercâmbio acerca da enfermagem enquanto trabalho social, disciplina do conhecimento científico e profissão do cuidado humano.

"Só sei que nada sei!". A famosa e categórica afirmação atribuída ao filósofo Sócrates, admitida e exaustivamente repetida, não espelha a parte mais nobre e central de seu pensar, nem faz jus ao valor intelectual desse filósofo. Sócrates se colocava frente ao seu interlocutor como alguém que nada sabia sobre o assunto, mesmo que já o soubesse, a fim de começar do zero e, juntos, chegarem a uma sabedoria mais apurada.

Porém, "só sei que nada sei" não condiz com o papel investigador e perspicaz que Sócrates desempenhou. De acordo com estudos contemporâneos, é uma afirmação simplista, modificada, um "trocadilho engenhado por estudiosos com o objetivo de tipificar a ironia socrática". Obedecendo ao texto original em grego escrito por Platão, Sócrates disse: "Eu, o que de fato nada sei, também não fico pensando que sei".

A frase caracteriza, conforme os pesquisadores Mauro Porcu e Ricardo Franzi (UEM), o pensamento deste filósofo, o qual diz que é justamente o fato dele não pensar que sabe o que não sabe, que o torna mais sábio que os outros.

Com relação ao conhecimento da enfermagem e seu fantástico crescimento, resta evidente que o profissional da área deve aprender a continuar aprendendo, selecionando assuntos, quanto sua origem e qualidade, sendo crítico em sua análise do que significa a evidência científica.

Com uma distribuição gratuita e de livre acesso na versão eletrônica, Enfermagem em Foco abre espaços para os profissionais de enfermagem expressarem suas opiniões e divulgarem seus trabalhos. Não é um veículo de comunicação voltado apenas para o mundo científico e com texto rebuscados, é também um espaço democrático, onde opiniões e informações vão se entrelaçar, resultando na melhor formação para todos os profissionais.

Os Conselheiros Federais do COFEN cumprem, portanto, mais um compromisso, e enxergam a necessidade inevitável de mudar, pois com a "força da mudança"', abre-se um universo que almejamos de uma sociedade melhor, mais justa e mais humana.

Boa leitura!

Manoel Carlos Neri da Silva

Presidente do Conselho Federal de Enfermagem 